\title{
PRZYCZYNEK DO ZAGADNIENIA SYMBOLIKI RÓŻY. DEKORACJA DRZWI SZAFY BRACKIEJ W KOŚCIELE PODOMINIKAŃSKIM W KLIMONTOWIE*
}

W zakrystii kościoła podominikańskiego p.w. Najšwiętszej Panny Marii i św. Jacka w Klimontowie przechowywana jest szafa polączona z komoda, wykonana w 4 ćw. XVII w. dla potrzeb działającego tam Bractwa Różańcowego?. Drzwi szafy pokryte są obustronnie malowidlami - awers zdobi scena Zwiastowania, rewers zaś - analogiczne na obu skrzydłach sceny adoracji śś. Katarzyny Sieneńskiej i Róży z Limy przez członka i członkinię Bractwa (rys. 1, 2). Popiersiowe wizerunki obu świętych umieszczone sa pośrodku dużych, kolistych, stylizowanych kwiatów róży, osadzonych na grubych, kolczastych łodygach, od których odchodza mniejsze odrosty, zakończone pąkami i kwiatami.

Dekoracja drzwi szafy zasługuje na szersze omówienie, nie tylko z racji stosunkowo wysokiego poziomu artystycznego (odnosi się to zwłaszcza do sceny Zwiastowania) lecz przede wszystkim ze względu na jej interesujący program ikonograficzny i symbolikę.

Niewątpliwie uwage widza $w$ pierwszej kolejności zwraca niecodzienna oprawa, jaka nadano wizerunkom śś. Katarzyny Sieneńskiej i Róży z Limy.

* Tekst niniejszy powstal w oparciu o komunikat wygloszony na sesji naukowej zorganizowanej przez Wydzial Historii Kościoła Papieskiej Akademii Teologicznej w Krakowie w maju $1992 \mathrm{r}$.

1 Katalog Zabytkóiv Sztuki w Polsce, T. 3, woj. kieleckie, zeszyt 11, pow. sandomierski. Warszawa 1962, s. 17, fig. 204. - Szafa datowana jest na 2 ćw. XVII w.; czas jej powstania należy raczej przesunać na 4 ćwierć tego stulecia, do czego sklania napis na banderoli ponad wizerunkiem św. Róży z Limy: S[ancta] Rosa a San Maria, który wskazuje, iż wykonano go po kanonizacji, która miala miejsce w $1671 \mathrm{r}$. 


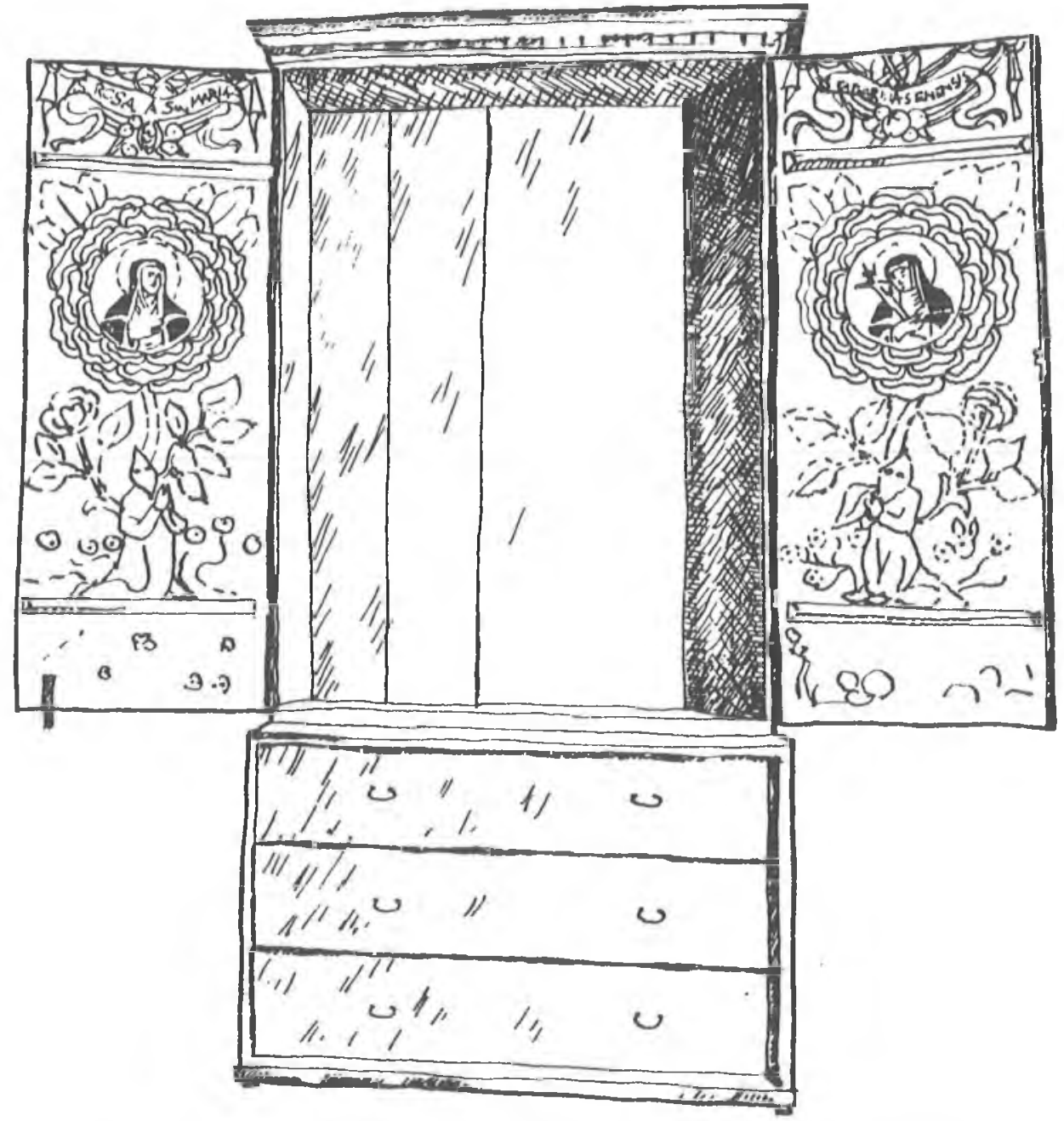

Rys. 1. Szafa Bractwa Różancowego w kuściele podominikariskim w Klimontowie

(Rys. Elıbietn Samek)

O ile bowiem przedstawienie obu świętych - których wygląd nie odbiega zreszta od konwencionalnych, wlaściwych im typów ikonngraficznych ${ }^{2}-$

2 Św. Katarzyna Sieneńska (ur. ok. 1347, zm. 1380, kanonizowana w 1461 r.) przedstawiana bywa $w$ habicie dominikańskim, $z$ korona cierniowa na glowie, $z$ krucyfiksem i lilią $w$ ręku; poza przedstawieniami samodzielnymi jej wizerunek pojawia się najczęściej obok postaci św. Dominika $w$ scenach wręczania im różanica przez Matkę Boską. Osobna grupę stanowia sceny jej mistycznych zaślubin. Szersze wiadomości na temat ikonografii św. Katarzyny ze Sieny por. m.in.: L. Reau, Iconographie de l'art chrétien, t. 3, iconographie des saints, cz. 1. Paris 1958, s. 272-277; H. Fros SI, F. Sowa, Twoje imię. Przewodnik onomastycznto-hagiograficzny. Kraków 1975, 


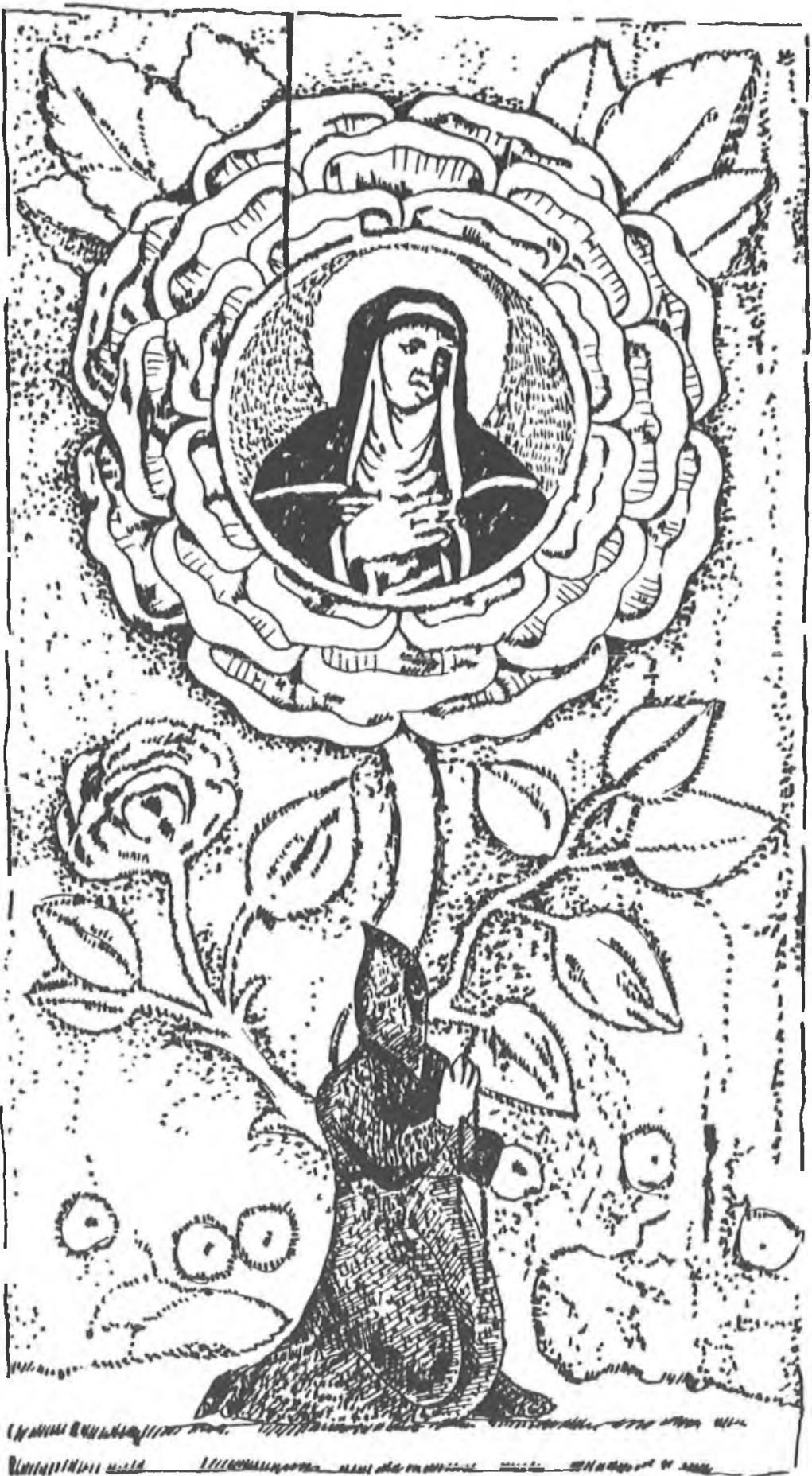

Rys. 2. Wizerunek św. Róży z Limy na drzwiach szafy 
w jednym dziele sztuki jest dość częste i nietrudne do wytłumaczenia ${ }^{3}$, o tyle unikalnym jest umieszczenie wizerunków świętych pośrodku kwiatu róży, wieńczącego lodygę $z$ odrostami. Źródeł tego typu rozwiazania upatrywać można $w$ przedstawieniach, jakie znamy np. $z$ ryciny Johana Wierixa (ur. 1549, zm. okolo 1615$)^{4}$ (rys. 3). Widać na niej okragly medalion z wizerunkiem Tronującego Dzieciątka Jezus, umieszczony pośrodku stylizowanego kwiatu lilii, osadzonego na ulistnionej łodydze. Forma, jaka nadano kwiatom róży na drzwiach szafy brackiej bliska jest również ksztaltom niektórych relikwiarzy $z$ epoki baroku. Zbliżony wygląd nadano np. górnej części relikwiarza św. Wojciecha z 1752 r. w kościele św. Wojciecha w Krakowie, przy czym w tym przypadku kwiat róży odnosi się do legendarnego herbu świętego - Poraj $j^{5}$. O wiele bliższa krzewom róży przedstawionym na zabytku z Klimontowa jest jednak forma relikwiarza z 1702 r. pochodzącego $z$ kościoła parafialnego p.w. N.P.Marii w Śmiglu, w województwie

s. 341; K.S. Moisan, Mntka Boska Różańcowa. W: Ikonografia nounożytnej sžluki kościelnej wo Polsce. Pod red. J. St. Pasierba. Now'y Testnment. T. 2, Maryjn orędowniczkn wientych. Warszawa 1987, s. 69-72. Ostatnio ukazal się bogato ilustrowany katalog wystawy poświęconej tej świętej: Catherine de Sienne. Crand Chapelle du Palais des Papes. Avignon 1992. - Św. Róża z Limy (ur. 1586, zm. 1617, kanonizowana w 1671 r.) wyobrażana jest jako mloda zakonnica dominikańska (niekiedy $z$ korona cierniowa na glowie), trzymająca $w$ ręku figurkę Dzieciątka Jezus lub galązkę kwitnącej róży; jej przedstawienie bywa czasami wlączone $w$ wiclopostaciowe sceny adoracji Matki Boskiej. Ikonografię św. Róży Limańskiej omawia m.in. Reau, o.c., cz. 3. Paris 1959, s. 1171-1172; Fros, Sowa, o.c., s. 471

${ }^{3}$ Obie święte widać m.in. na malowidle ściennym zdobiącym kaplicę Lubomirskich przy kościele O.O. Dominikanów w Krakowie (Katalog Zabytków Sztuki w Polsce, T. 4, m. Krakówo, cz. 3, kościoły i klasztory Śródmieścin 2. Warszawa 1978, s. 136); w samym Klimontowie znajdowal się obraz przedstawiajacy "Pana Jezusa miẹdzy córami św. Dominika jak między liliami wirydarza rajskiego", a wśród owych cór umieszczono m.in. śś. Różę z Limy i Katarzynę Sieneñska (W. Kukliński, Opis historyzzny kościotów klimontouskich, Kościół $i$ klasztor dominiknnớr. "Kronika Diecezji Sandomierskiej”. R. 3:1910, s. 444); posagi obu świętych wieńczą też attyki boczne przedsionków kościola OO. Dominikanów we Lwowie (Z. Hornung, Mrjster Pinsel, snycerz. Kartn z dziejów polskiej rzé́by rokokowej. Wroclaw 1976, s. 105, il. 74, 80). Przedstawienie obok siebie obu świętych tłumaczyć można wielorako - obie byly dominikankami, gorliwymi wyznawczyniami kultu maryjnego, obie uznane sa oblubienicami Chrystusa, podobnie wreszcie przebiegaly koleje ich drogi do świętości. Trzeba też przypomnieć, że św. Róża obrala sobie za wzór św. Katarzynę Sieneńską i tà kilkakrotnie jej się objawiala (W. Zaleski SDB, Śzvięci na knzdy dzień. Warszawa 1989, s. 492).

+ M. Mauquoy-Hendrickx, Les estampes des Wierix conseroees au Cabinet des estampes de la Bibliotheque Roynle Albert Ier. Catalogue raisontné, part 1. Bruxelles 1978, il. 476 na s. 61 . Na innej, niesygnowanej rycinie wewnątrz kwiatu irysa wieńczacego lodygę z liśćmi widać owalny medalion z Chrystusem Bolesnym (ibidem, il. 519 na s. 67).

5 Katalog Zabytków Sztuki wo Polsce, T. 4, o.c., fig. 961; J. Samek, Res-imagines. Ze studiów nad rzemiostem artystycznym cznsóu nowoożytmych w Polsce (lata 1600-1800). "Rocznik Historii Sztuki”. T. 6:1979, s. 237 (omawiajac symbolikę relikwiarza autor dodaje, iż w średniowiecznej hymnologii św. Wojciech przyrównywany byl do róży). 


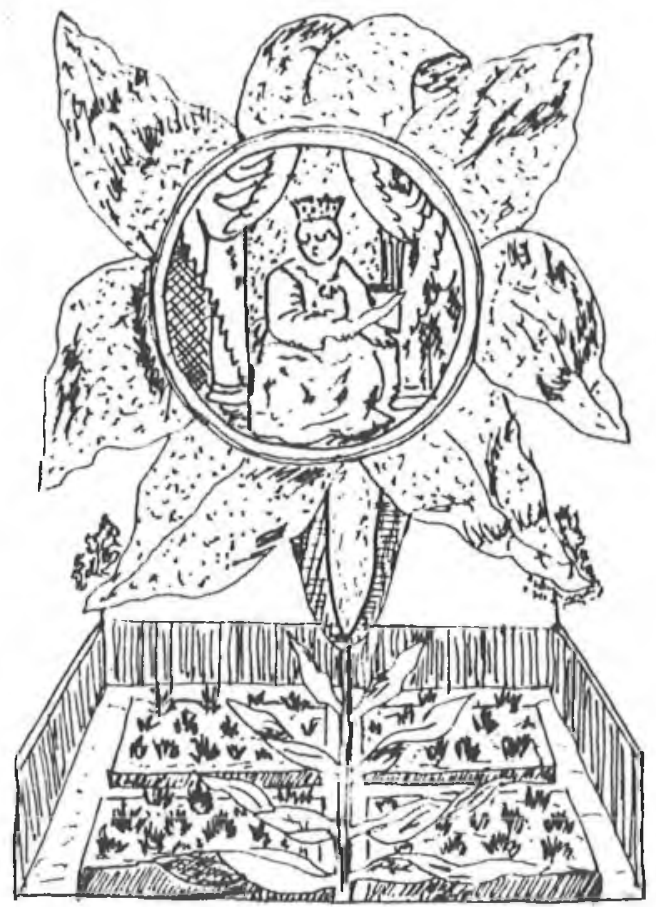

Rys. 3. Rycina Johana Wierixa

(Rys. Mirostaw /. Stec)

poznańskim ${ }^{6}$ (rys. 4). Kształt kwiatów, platków a także obecność bocznych odgalęzień jest $w$ obu przypadkach tak bliski, niemal identyczny, że sklania do przypuszczenia, że na ich formę mógł wpłyną́ wspólny wzór graficzny.

Nim wskażemy ryciny, które być może pelnily rolę takiego wzoru warto poświẹcić nieco uwagi formie, jaką nadano kwiatom róży. Zarówno na malowidle zdobiącym drzwi szafy jak i w relikwiarzu ze Śmigla kwiatostan odbiega swym wyglądem od kwiatów róży spotykanych $w$ naturze - ma formę płaska i przypomina raczej kwiat widziany z góry. Specyficznie potraktowane i rozmieszczone są również płatki - mają one miękko zarysowane, wklęslo-wypukle krawędzie i ułożone sa promieniście wokół centralnego "medalionu”. Również wygląd krzewu różanego na drzwiach szafy brackiej nosi cechy pewnej stylizacji - nie jest to właściwie krzew, lecz raczej masywna, kolczasta lodyga o kilku odrostach, $\mathrm{z}$ których dolne, biegnace poziomo usiane są drobnymi kwiatami, zaś górne, ułożone ukośnie - zakończone niewielkim,

6 J. Samek, Ostensoria w formie róży (na marginesie rozważń nad monstrancja w Strumieniu). "Rocznik Cieszyński”. T. 2:1972, s. 85, il. 5; Katalog Zabytków Sztuki w Polsce, T. 5, woj. poznańskie, zeszyt 11, pui. krotoszyński. Warszawa 1973, s. 101, fig. 450. Autorzy sugeruja iż relikwiarz - dzielo zlotnika poznańskiego, Krzysztofa Neumana - pierwotnie używany był zapewne jako monstrancja. 


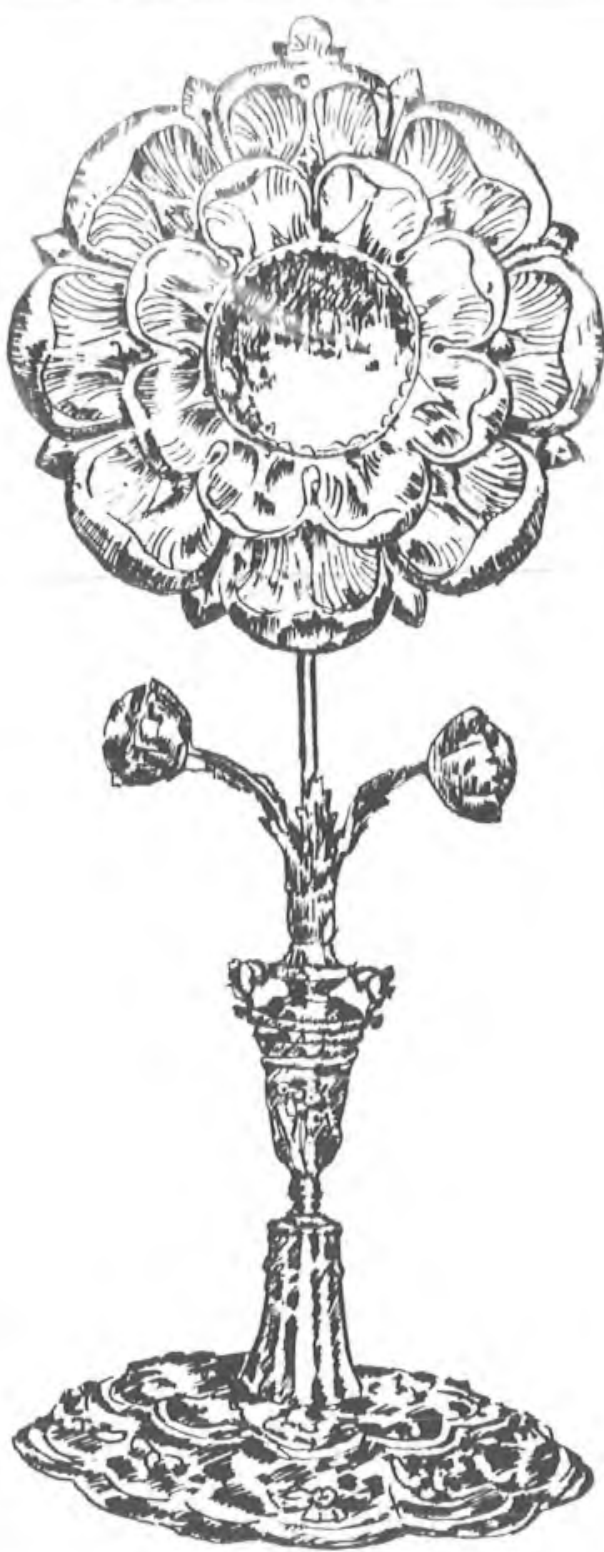

ikys. 4. Kelıkwiarz z kościola N.P.Marii w Smiglu

(Ry/s. Elı̈bietn Snmek)

nie $\mathrm{w}$ pełni rozwiniętym kwiatem i pąkiem. Zwraca uwagę to, iż te ostatnie odgałęzienia, zwlaszcza ich liście i paki, potraktowane sa w pehni realistycznie.

Bardzo zbliżone krzewy różane przedstawione sa na rycinie wykonanej według sztychów Philip'a Galle (1537-1612) przez Adriana Collaerta, 


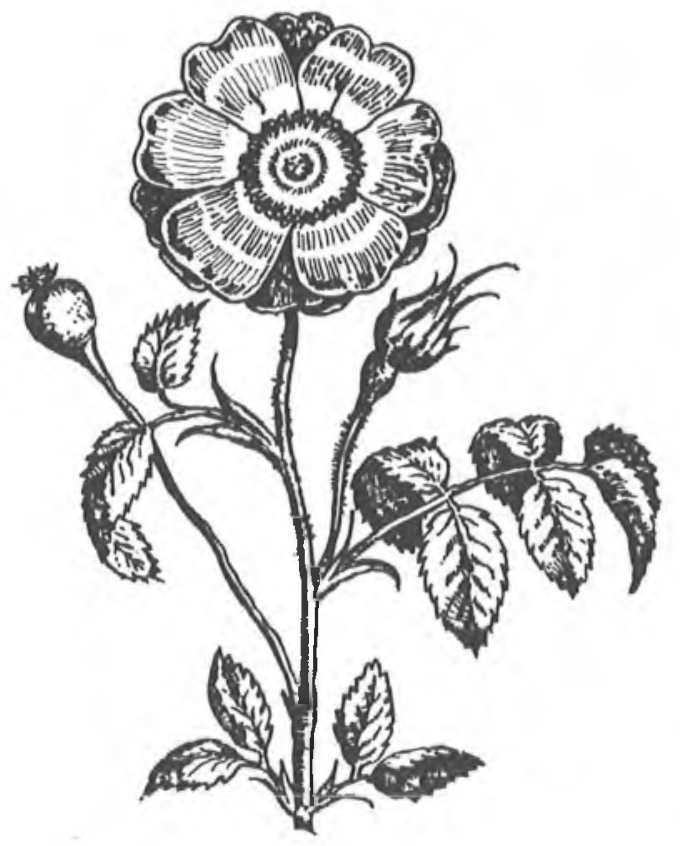

Rys. 5.

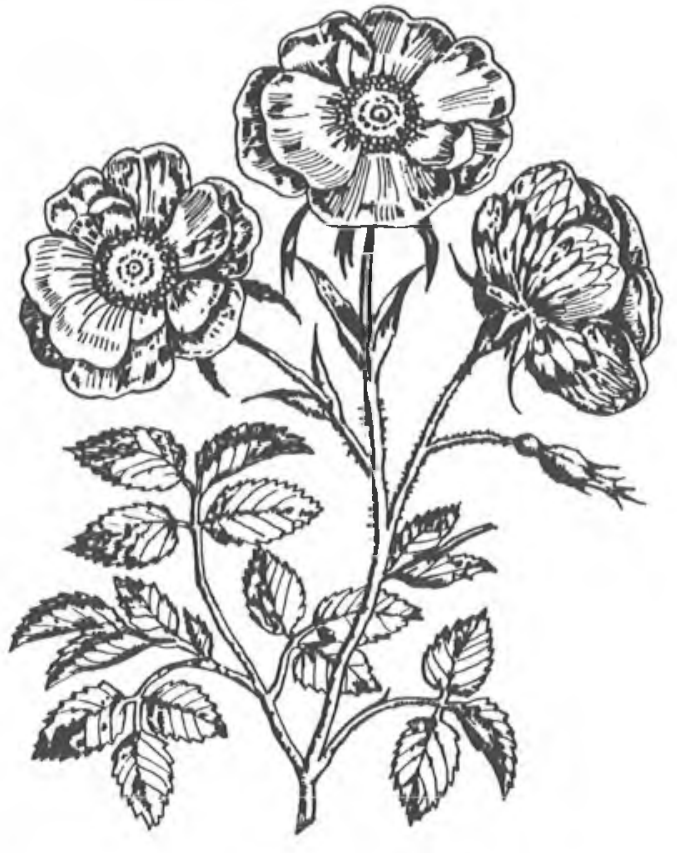

Rys. 6.

Rys. 5-6. Fragment ryciny Adriana Collaerta wg sztychów Philip'a Galle

(Rys. El:ibieta Snmek)

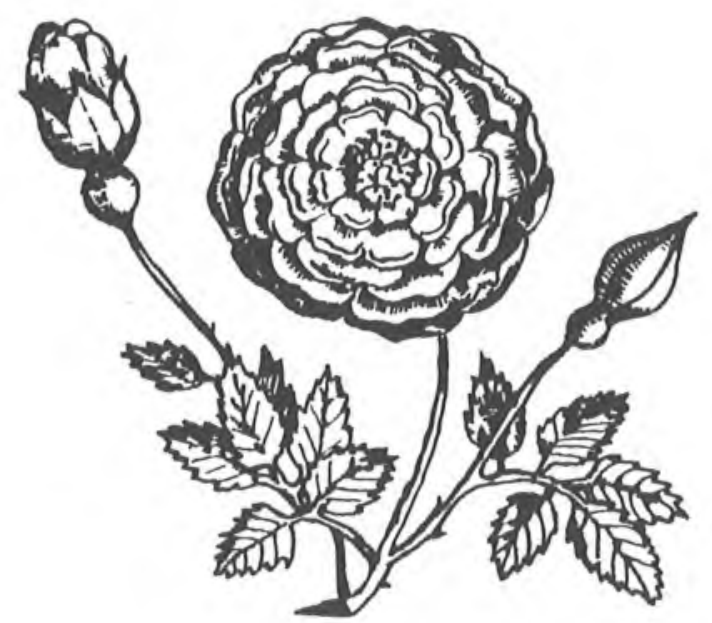

Rys. 7. Fragment ryciny Adriana Collaerta wg sztychów Philip'a Galle

(Rys. Elżbieta Samek) 


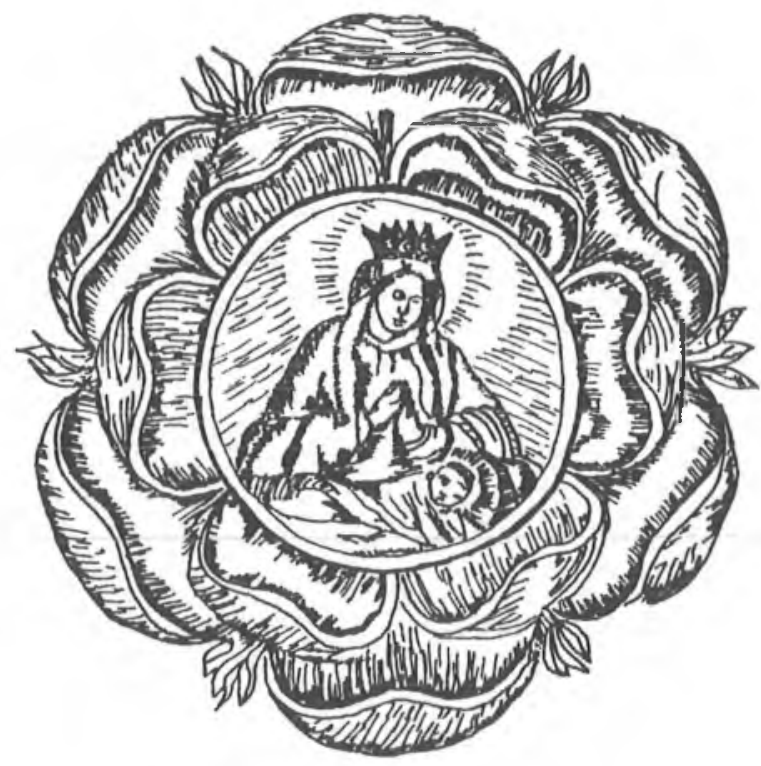

Rys. 8. Drzeworyt z 2 pol. XVI w.

(R!/s. Mirostuze /. Stec)

działajacego $w$ Antwerpii w latach $1560-1618^{7}$ (rys. 5-7). Choć stylizacja wyglądu kwiatów na rycinie nie jest posunięta tak dalece, jak na drzwiach szafy, czy $w$ relikwiarzu ze Śmigla, to latwo zauważyć podobieństwa $w$ potraktowaniu płatków dużych kwiatów wieńczących gałązi. Również wygląd, jaki malarz nadal pąkom i rozkwitającym kwiatom $w$ zakończeniach odrostów bliski jest formom widocznym na rycinie. Natomiast niemal identycznie potraktowany kwiat róży, w który - podobnie, jak na drzwiach szafy brackiej - wkomponowano medalion z pólpostacią Matki Boskiej adorującej Dzieciątko widać na anonimowym polskim drzeworycie z 2 poł. XVI w. ${ }^{8}$ (rys. 8 ).

Z kolei należy zastanowić się, dlaczego przedstawieniom św. Róży z Limy i św. Katarzyny Sieneńskiej nadano tak oryginalne, niespotykane oprawy a także podjąć próbę wyjaśnienia ich symbolicznego znaczenia.

Na wstępie przypomnijmy, że szafa, którą zdobią owe wizerunki należała do Bractwa Różańcowego, działającego przy kościele Ojców Dominikanów w Klimontowie. Zrozumialym wydaje się więc, że przedstawienia obu świętych umieszczono wewnątrz kwiatów róży, które budzą skojarzenia

7 Zauber des Onaments. Ausstellung und Bestandkatalog des Kupferstichkabincttes. Berlin 1969, tabl. 285 na s. 105.

$8 \mathrm{~J}$. Muczkowski, Zbiór drzezoorytów wo różnych dzieluch polskich wo XVI i XVII wieku odbitych a teraz w Bibliotece Uniwersytett Jagiellońskiego zachowanych. Kraków 1849, il. 524 na s. 76. 
z samą nazwą różańca, zwanego też w XVI i XVII w. "ogrodem różanym” lub „różanym wiankiem Panny Marii"

Krzewy różane można też odczytywać jako doslowną ilustrację wizji Raju św. męczenniczki Perpetui, która oglądała ogród rozkoszy, w którym kwitly „drzewa różane"oraz wszelkiego rodzaju kwiaty ${ }^{10}$.

W przypadku św. Róży Limańskiej można też traktować kwiat róży, wewnątrz którego umieszczono jej wizerunek, jako przedstawienie atrybutu tejże świętej.

Wolno również przypuszczać, że nadanie wyobrażeniom obu świętych takiej wlaśnie oprawy może stanowić nawiązanie do pewnych faktów $\mathrm{z}$ ich życia. Św. Róża otrzymała na chrzcie imię Elżbieta; dopiero gdy matka pewnego dnia zobaczyla na twarzy swej śpiącej córki kwiat róży, zaczęto nazywać ją Różą ${ }^{11}$. Jej biografowie podkreślaja, że stosownie do swego imienia była bardzo piękna, a większość swego wolnego czasu spędzała w ogrodzie, w zażyłej przyjaźni z otaczająca ją przyrodą ${ }^{12}$. Co do św. Katarzyny Sieneńskiej legenda podaje, że lubila ona bardzo kwiaty, szczególnie zaś róże ${ }^{13}$.

W rozważaniach nad symboliką malowideł zdobiących drzwi szafy brackiej z Klimontowa bardzo istotnym wydaje się być fakt, iż malarz przedstawił krzew róży o lodygach usianych kolcami. Klucz do odczytania ukrytej w takiej formie treści znajdujemy w dziele Joannesa Michaela van der Ketten "Apelles Symbolicus...", wydanym w Amsterdamie i Gdańsku w 1699 r. ${ }^{14}$. W rozdziale poświęconym róży, pośród trzydziestu czterech jej znaczeń, odnajdujemy kilka pozycji dotyczących róży z kolcami. Tak więc, za pomoca róży z kolcami wyobrazić można cierpliwość i uległość wobec przeciwności duchowych ${ }^{15}$; chotę, którą z trudem można osiągnąć bez przeciwności ${ }^{16}$; umartwienie niemile

${ }^{9}$ Zwraca na to urvage Moisan, o.c., s. 58. Nazwy te pojawiaja się $w$ tytułach licznych dziel poświęconych modlitwie różańcowej, wśród nich wymienić moźna: Benedykta Herbesta "Rózantego

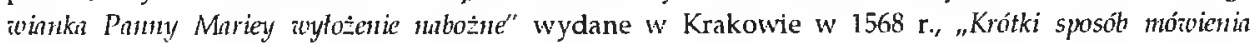
psatterzyka Panny Maryey rożanki abo różny winnek..." wydany po 1611 r., Waleriana Andrzejowicza "Ogród róṫny albo opisanie porzqdne dau szczepów aronney Różey Hierychuntskiey..." wydany w Krakowie w 1627 r. oraz Jacynta Sirakowskiego „Wieniec rółnny Królowej Niebieskiej” wydany w Poznaniu w 1644 r.

10 D. Forstner OSB, Śuint symboliki chrześcijnúskiej. Przeklad i opracowanie Wanda Zakrzewska, Pawel Pachciarek i Ryszard Turzyński. Warszawa 1990, s. 192.

11 A. Nowowiejski, Ró̇n z Linn. W: Encyklopetin Kościehta, podtıg teologicznej encyklopetii Wetzera i Weltego. Wyd. M. Nowodworski, T. 23. Warszawa 1899, s. 536. - Sama święta wybrała dla siebie z polecenia Najświętszej Panny Marii imię: Róża od Najświętszej Panny Marii (Rosa a San Maria) (ibidem, s. 537).

12 Legendy dominikańskie. Tuum. Jacek Salij OP. Poznań 1982, s. 26.

13 M.H. Jette, Sivięta Katarzyna ze Sieny. Tlum. Janusz Mazur. Warszawa 1979, s. 27.

1+ J.M. van der Ketten, Apelles Symbolicus exhibens serie amplissimam symbolorum..., pars. 2.Amstelaedami-Gedani 1699.

15 Ibidem, s. $56, \mathrm{nr} 237$.

16 Ibidem, s. 57, nr 247. 
cialu, dla ducha zaś przyjęte ${ }^{17}$ a także przyjemności, których należy kosztować z zachowaniem ostrożności ${ }^{18}$.

Symbolika róży z kolcami wiąże się więc z czyhającymi na osoby dążące do osiagnięcia idealu duchowego przeszkodami, pokusami i przeciwnościami, których nie szczędzi życie doczesne; przeszkody te pokonać jednak można dzięki cierpliwości, umiarowi i umartwieniu.

Taka wlaśnie postawę reprezentowały obie święte. Ich droga ku świętości nie byla latwa - przeciwnie, obfitowala $w$ wiele trudów $\mathrm{i}$ przeciwności. Jak czytamy w żywocie św. Róży z Limy, przez dwanaście lat doznawala ona od Boga wielkiej "oschłości”, czuła się przezeń odrzucona. Byla to dla niej najstraszniejsza męczarnia, prawdziwa "droga krzyżowa". Nie bylo też cnoty, $w$ której by się nie ćwiczyła i umartwienia, któremu by się nie oddawala. Do każdej rzeczy, która przypominala próżność lub życie doczesne dolaczała umartwienie; np. nosila koronę z cyny, później zaś ze srebra, raniącą jej skórę. $Z$ każdego doświadczenia wychodziła jednak coraz to pokorniejsza i wytrwalsza w znoszeniu cierpień i pokus, których Bóg jej nie szczędzi1 ${ }^{19}$.

Podobną siłę w zwalczaniu pokus i trudności oraz cierpliwość w znoszeniu upokorzeń wykazywała też św. Katarzyna Sieneńska. I ona poddawała się licznym umartwieniom, czyniąc np. trzechletni ślub milczenia ${ }^{20}$.

Nieprzejednana postawa i cierpliwość obu świętych wyplywala $z$ wielkiej milości do Boga. I tę cnotę symbolizuje róża z kolcami. Joannes Michael van der Ketten pisze bowiem, iż można wyobrazić $w$ ten sposób tego, kto najgorliwiej kocha Boga ${ }^{21}$.

Warto też zasygnalizować, że powtarzająca się zarówno na zabytku klimontowskim, jak i w relikwiarzu ze Śmigla ilość ośmiu płatków kwiatu róży również może mieć znaczenie symboliczne. Jeszcze bowiem w średniowieczu mnich Beda odnosil liczbę osiem m.in. do ośmiu cnót, powołując siẹ na wskazania św. Piotra ${ }^{22}$, który w Drugim liście zaleca: "Dlatego też wlaśnie wkladając cała gorliwość, dodajcie do wiary waszej cnotę, do cnoty poznanie, do poznania powściagliwość, do powściagliwości cierpliwość, do cierpliwości pobożność, do pobożności przyjaźń braterską, do przyjaźni braterskiej zaś miłość" (2P, 1,5-7). Nie można wykluczyć, że twórca naszych przedstawień $\mathrm{W}$ ten wlaśnie symboliczny sposób pragnął podkreślić cnoty obu świętych.

Podsumowując powyższe rozważania stwịerdzić należy, że umieszczenie wizerunków św. Róży z Limy i św. Katarzyny Sieneńskiej pośrodku kwiatów

\footnotetext{
17 Ibidem, s. 59, nr 261.

18 Ibidem, s. 59, nr 262.

19 A. Nowowiejski, Róża z Limy. W: Encyklopedia Kościelna..., o.c., s. 537.

20 lbidem, T. 10, Warszawa 1877 , s. 186-187.

21 Van der Ketten, o.c., s. 58, nr CCLV.

22 H. Meyer, Die Zahlenallegorese im Mittelalter. Methode und Gebrauch. München 1975, s. 140-141.
} 
wieńczących kolczaste krzewy różane nie bylo przypadkowe i wiąże się z przekazaniem określonych treści symbolicznych.

Pozostaje jeszcze do wyjaśnienia problem związku omówionej dekoracji rewersu drzwi szafy brackiej z przedstawiona na ich awersie sceną Zwiastowania, pozornie niewiele mającą wspólnego z szeroko pojętą symboliką róży. Jednak uzasadnienie dla wyboru takiej wlaśnie sceny znajdujemy $w$ dziele ks. Waleriana Andrzejowicza „Ogród różany albo opisanie porządne dwu szczepów wonney róży..." wydanym w Krakowie w 1627 r. Dowodzi on, że „... nie bez przyczyny to anielskie pozdrowienie przypodabia się do róży, bo jak to kwiat różany rodzi się na drzewku i z swego szczepia wynika, tak pozdrowienie anielskie wyniknẹlo z serca Boga Ojca a przez Archanioła do Najświętszej Panny zaniesione jest (...) Pan Bóg tych ludzi, którzy to pozdrowienie często odprawiali na cześć błogosławionej Panny y za żywota y po śmierci kwiatami różanemi glowy $y$ usta $z$ wielkim podziwieniem przyozdabiał; zaczym musi się przyznać, że to pozdrowienie słusznie się do róży przyrównywa" ${ }^{23}$.

Dekoracje drzwi szafy brackiej z kościoła $w$ Klimontowie można więc traktować jako krótki wykład na temat zadań i celów - oraz sposobów ich osiagania - stojących przed członkami Bractwa, dokonany za pomoca szeroko pojętego symbolicznego znaczenia róży. Dekoracja awersu odnosi się do zadań stawianych czlonkom Bractw Różańcowych, a więc krzewienia kultu maryjnego poprzez odmawianie modlitwy różańcowej, której zasadniczą część stanowi "Zdrowaś Maryjo..." - owo przyrównywane do róży pozdrowienie anielskie, zilustrowane sceną Zwiastowania. Dekoracja rewersu drzwi odnosi się natomiast do celu, jakim jest osiagnnięcie wiecznej szczęśliwości, wejście do ogrodu rajskiego, zobrazowanego poprzez krzewy różane. Ta część dekoracji ilustruje również sposób osiągnięcia tego celu - wyobrażony poprzez usiany kolcami krzew różany - wzorem św. Róży z Limy i św. Katarzyny Sieneńskiej cierpliwie znosić pokusy i pokonywać przeciwności losu, czerpiąc siłę z wielkiej milości do Boga i skladając mu w ofierze umartwienia.

23 Andrzejowicz, o.c., s. 12-13. 